\title{
9- Yabancı dil olarak Türkçe öğretimi sertifika programlarının etkinliği üzerine bir durum çalışmasıı ${ }^{1}$
}

\section{Z. Canan CANDAȘ²}

\section{Serdar BAŞUTKU3}

APA: Candaş, Z. C.; Başutku, S. (2021). Yabancı dil olarak Türkçe öğretimi sertifika programlarının etkinliği üzerine bir durum çalışması. RumeliDE Dil ve Edebiyat Araştırmaları Dergisi, (Ö10), 158170. DOI: 10.29000/rumelide.1009055.

$\ddot{O} \mathbf{z}$

Yabancı dil olarak Türkçenin öğretimi son yıllarda daha çok ilgi görmesine rağmen bu alan için öğretmen yetiştirmede gerekli adımlar atılamamıştır. Lisans düzeyinde bölüm bulunmaması önemli bir eksikliktir. Son yıllarda bu özel alan için gereksinim duyulan öğretmenler sertifika programları ve hizmet içi eğitimlerle yetiştirilmektedir. Bu sertifika programları ve hizmet içi eğitimlere çoğunlukla Türkçe öğretmenliği, Türk dili ve edebiyatı bölümlerinden lisans eğitimi alan öğretici adayları katılmaktadır. Yabancı dil olarak Türkçenin öğretimi anadili olarak Türkçenin öğretiminden çok farklıdır. Her ne kadar ana başlık olarak Türkçenin eğitimi ya da öğretimi olarak adlandırılabilse de Yabancı dil olarak Türkçenin öğretimi içerik, öğrenim, öğretim yöntem ve teknikleri açısından çok farklı özellikleri içerir. Yabancı dil olarak Türkçenin öğretimi alanında öğreticiler yetiştirmek amacıyla düzenlenen sertifika programlarını işleyişi ve içeriği açısından katılımcıların görüşleri aracılığıla incelemeyi hedef alan bu çalışma var olan durumu tanımlamayı ve daha sonra oluşturulacak programlar için ilkelerin belirlenmesini amaçlamıştır. Bu araştırmanın verileri, Türkçenin yabancı dil olarak öğretimi alanında eğitici olarak çalışacak bireylere sertifika programı düzenleyen Hitit Üniversitesi Türkçe Öğretimi Uygulama ve Araştırma Merkezi tarafından 18 Ocak5 Şubat 2021 tarihleri arasında verilen eğitimle sınırlandırılmıştır. Sertifika programlarının genel özelliklerini yansıtan bir sertifika programı ele alınmıştır. Bu kapsamda bir grup katılımcı örneklem olarak ele alınmış ve derinlemesine veri toplamak amacıyla incelenmiştir. Bu çalışmadan çıkan verilerin daha sonra geliştirilecek sertifika programların geliştirilmesine katkı sağlayacağı var sayılmaktadır.

Anahtar kelimeler: Yabancı dil olarak Türkçe öğretimi, sertifika programları, öğretici yeterlikleri

\section{A case study on the effectiveness of certificate programs in teaching Turkish as a foreign language}

\author{
Abstract \\ Although the teaching of Turkish as a foreign language has received more attention in recent years, \\ the necessary steps have not been taken in training teachers for this field. The absence of a degree \\ level is a significant deficiency. In recent years, teachers needed for this special field have been trained \\ $1 \quad$ Hitit Üniversitesi, Girişimsel Olmayan Araştırmalar Etik Kurulunun 2021-139 sayllı yazısı ile araştırma için gerekli olan \\ etik kurul izni alınmıștır. \\ Doç. Dr., Ankara Üniversitesi, Eğitim Fakültesi, Türkçe Eğitimi Bölümü (Ankara, Türkiye), ra.canan2017@gmail.com, \\ ORCID ID: 0000-0002-5969-3599 [Araştırma makalesi, Makale kayıt tarihi: 26.09.2021-kabul tarihi: 20.10.2021; DOI: \\ 10.29000/rumelide.1009055] \\ Öğr. Gör., Hitit Üniversitesi, Türkçe Öğretimi Uygulama ve Araştırma Merkezi (Çorum, Türkiye), \\ serdarbasutku@hitit.edu.tr, ORCID ID: 0000-0003-2507-2089 \\ Adres $\mid$ Address \\ RumeliDE Dil ve Edebiyat Araştırmaları Dergisi $\quad$ RumeliDE Journal of Language and Literature Studies \\ Osmanağa Mahallesi, Mürver Çiçeği Sokak, No:14/8 Osmanağa Mahallesi, Mürver Çiçeği Sokak, No:14/8 \\ Kadıköy - ISTANBUL / TÜRKIYE 34714 Kadıköy - ISTANBUL / TURKEY 34714 \\ e-posta: editor@rumelide.com e-mail: editor@rumelide.com \\ tel: +90 505 7958124, +90 2167730616 phone: +90 505 7958124, +90 2167730616
}


through certificate programs and in-service training. These certificate programs and in-service trainings are mostly attended by instructor candidates who have received undergraduate education from Turkish teaching, Turkish language and literature departments. The teaching of Turkish as a foreign language is very different from the teaching of Turkish as a native language. Although it can be called the education or teaching of Turkish as the main title, the teaching of Turkish as a foreign language contains many different characteristics in terms of content, learning, teaching methods and techniques. This study, which aims to examine the certificate programs organized in order to train tutorials in the field of teaching Turkish as a foreign language, through the opinions of the participants in terms of their functioning and content, aimed to define the existing situation and to determine the principles for the programs to be created later. The data of this research are limited to the education given between January 18 and February 5, 2021 by Hitit University Turkish Teaching Application and Research Center, which organizes a certificate program for individuals who will work as educators in the field of teaching Turkish as a foreign language. A certificate program that reflects the general characteristics of certificate programs is discussed. In this context, a group of participants were treated as samples and examined for the purpose of collecting in-depth data. It is assumed that the data from this study will contribute to the design and development of future certificate programs.

Keywords: Turkish teaching as a foreign language, certificate programs, teacher qualifications

\section{Giriş}

Öğretmen eğitimi, öğretim yöntem ve teknikleri açısından yabancı dil olarak Türkçe öğretimi geçmişi çok eski olmamakla birlikte 1980’li yıllardan sonra özellikle yurt içinde Türkçe ve Yabancı Dil Uygulama ve Araştırma Merkezlerinin (TÖMER, DİLMER) açılmasıyla Türkçenin yabancı dil olarak öğretimi daha da etkinleşmiştir. Böylelikle alanda çeşitli araştırmalar yapılmış ve kaynak eserler verilmeye başlanarak uzman öğretim elemanları yetiştirilmiştir. Yabancı dil olarak Türkçenin öğretiminde teorik bilgi ve pratik uygulama derslerinin olduğu sertifika programları ve hizmet içi eğitimlerin düzenlenmesine rağmen bu alan için öğretmen yetiştirmede gerekli adımlar atılamamıştır. Çeşitli üniversitelerde son yıllarda açılan ve lisansüstü düzeyde eğitim veren "Yabancı Dil Olarak Türkçenin Öğretimi” programları bu konudaki gereksinimi gidermeye çalışmaktadır. Ancak Türkçeyi yabancı dil olarak öğretecek niteliğe sahip öğretici gereksinimini karşılamak için lisans düzeyinde bölüm bulunmaması önemli bir eksikliktir.

Son yıllarda ülkemize yönelik düzensiz göçlerin artması ve uluslararası öğrencilerin sayısının fazlalaşmasıyla farklı kültür ve kimliklerin bir araya geldiği çokdilli ve çokkültürlü ortamların yoğunluğu dikkat çekmektedir. Bu duruma ek olarak Türkiye'nin tarihî ve kültürel etki alanındaki ülkelerin yanı sıra uzak coğrafyalardaki ülkelerde de özellikle Türk dizilerine ve filmlerine karşı olan ilgi Türkçe öğretiminin yaygınlaşmasına katkı sağlamaktadır. Özellikle 2008 yılı ve sonrasında yurt dışında Türk tarihini, kültürünü tanıtmayı ve Türkçe öğretmeyi hedefleyen kurumların (Yunus Emre Enstitüsü, Yurt Dışı Türkler ve Akraba Topluluklar Başkanlığı, Maarif Vakfı) açılmasıyla birlikte yabancı dil olarak Türkçe öğretimini gerçekleştirecek nitelikli öğretim elemanlarına son yllarda daha fazla ihtiyaç duyulmaktadır. Bu ihtiyacı karşılamak amacıyla çeşitli üniversitelerin bünyesinde yabancı dil olarak Türkçenin öğretimi yüksek lisans ve doktora programları açılsa da sertifika programları ile hizmet içi eğitim seminerleri düzenlenmektedir. Alanyazında yabancı dil olarak Türkçe öğretimi sertifika programlarını doğrudan konu alan çalışmalarda (Kurt, 2020; Bulut, 2020) Yabancı dil olarak Türkçe öğretimi sertifika programına katılan kursiyerlerin görüşlerini ortaya koyarak sertifika programlarına yönelik bir değerlendirme yapılmıştır. Bahse konu çalışmalarda çeşitli üniversiteler tarafından gerçekleştirilen sertifika programlarının teorik ve uygulamalı olarak gerçekleştirdiği ders saatlerine ve

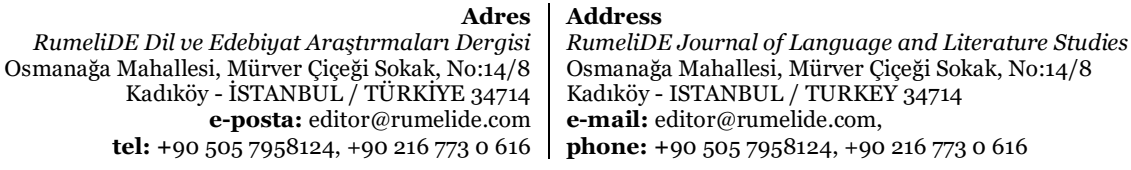


A case study on the effectiveness of certificate programs in teaching Turkish as a foreign language / Z. C. Candaş; S. Başutku (pp. 158-170)

bunların yeterli olup olmadığına dair tespitlere de yer verilmiştir. Kursiyer görüşlerine yönelik bu çalışmalara ek olarak Çelik (2021) yaptığı araştırmada sertifika programı düzenleyen kurumlardan da görüşler alarak bahse konu sertifika programlarının nitelik açısından iyileştirilmesine yönelik önerilerde bulunmuştur. Özellikle Covid-19'un sebep olduğu pandemi sürecinde sertifika programlarının çevrimiçi olarak gerçekleştirilmesi hem yurt dışından hem de yurt içinden öğretici adaylarının sertifika programına erişimini kolaylaştırarak daha çok üniversitenin bu programı düzenlemesine imkân sağlamıştır. Ancak düzenlenen söz konusu sertifika programlarının çoğalmasıyla birlikte içeriklerindeki farklılıklar ve ders veren öğretim elemanlarının farklı alanlardan olması sebebiyle bu programlara yönelik bir standardın olmadığını göstermektedir. Bu nedenle "yabancılara Türkçe öğretimi öğretmenliğinin farklı bir alan olarak henüz lisans düzeyinde ele alınmamış olması ve bu disipline özgü çalışmaların lisansüstü düzey ile sınırlı kalması” söz konusu programlarda bir standartlaşma sorununu da beraberinde getirmektedir (Barın, Çangal ve Başar, 2017: 82). Sertifika programlarındaki teorik ve uygulamaya yönelik ders saatlerinin düzenleyen kuruma göre farklllık göstermesi söz konusu programların belirli bir standardı sağlayamamasının nedenlerinden biri olarak görülmektedir.

Türkçe öğretiminin farklı alt dallara ayrılarak uzmanlaşma sağlanmasının önemine değinen Demir, (2021: 966) Türkçe öğretmenlerinin/öğreticilerinin pedagojik yeterlikleri üzerine bir değerlendirme adlı çalışmasında "Türkçe öğreticilerinin büyük oranda Türkçe ve Türk dili edebiyatı öğretmenliği bölümlerinde yetiştirildiğini ancak Türkçe öğretiminin faaliyet alanlarına göre uzmanlık gerektiren alanlara ayrıldığını" belirtmektedir. Bu alanların ise "Ana dili olarak Türkçe öğretmeni, ikinci/yabancı dil olarak Türkçe öğreticisi ve iki dillilere Türkçe öğreticisi” olmak üzere üçe ayrılabileceğini ifade etmektedir. Bu nedenle Demir (2021: 967) çalışmasında "öğreticilerin, taşıması gereken pedagojik yeterliklerin de genel pedagoji bilgisiyle uyumlu biçimde ancak branşların gerekliliklerini de gözetecek şekilde düzenlenmesi gerektiğini” önemle vurgulamaktadır. Bu kapsamda Karababa Türkçenin yabancı dil olarak öğretimi ve bu alan için öğretmen yetiştirmenin gereğini vurguladığı çalışmasında "öğretmen yeterlikleri açısından alan bilgisinin önemi, dilbilgisel yeterlik ve öğretme, öğrenme süreçlerine” dikkat çekerek önerilere yer vermiştir (Karababa, 2010: 26). Özellikle Türkiye içinde ve dışında Türkçenin öğretiminin nitelikli bir şekilde gerçekleştirilebilmesi için öğretici adaylarının özel alan yeterliklerine göre farklı teorik dersleri almaları ve pratik uygulamaları yapmaları gerektiği önemli bir ihtiyaç olarak karşımıza çıkmaktadır.

1990 yllından günümüze kadar geçen sürede yabancı/ikinci dil olarak Türkçe öğretiminde karşılaşılan sorunların başında genellikle evrensel standartlara sahip ders araç-gereçleriyle öğretmen yetiştirme ve öğretmen yeterliliklerinin belirsizliği konusu gelmektedir. Türkçenin yabancı/ikinci dil olarak öğretimi konularında karşılaşılan sorunlarla, bu sorunların çözümlerine dair öneriler sunulan konularla ilgili yapılmış bazı çalışmalarda (Güzel, 2003; Açık, 2008; Candaş-Karababa, 2009; Alyılmaz, 2010; Kara, 2010; Er, Biçer ve Bozkırll, 2012; Durmuş, 2013; Boylu ve Başar, 2016; Kalenderoğlu, 2019) ortak görüşler mevcuttur. Burada bahsi geçen çalışmalarda doğrudan veya dolaylı olarak sunulan veriler dikkate alındığında yabancılara Türkçe öğretimine yönelik genel ve ortak sorunların tespitinin yapıldığ 1 görülmektedir. Belirtilen çalışmalarda yabancı/ikinci dil olarak Türkçenin öğretiminin ortak sorunu olarak genellikle yurt içinde üniversitelerin bünyesinde faaliyet gösteren TÖMER birimlerinin işleyişindeki düzensizlik, kullanılan ders araç-gereçlerin evrensel standartlara uygunluğu ve öğreticilerin yetkinliği olarak gözlemlenmiştir. Belirtilen çalışmaların tamamında en önemli sorulardan biri olarak görülen ortak konun yabancı/ikinci dil olarak Türkçe öğretimi alanında nitelikli öğretmen ihtiyacı olduğu tespit edilmiştir. Bu sebeple bu çalışmada Yabancı dil olarak Türkçenin öğretimi alanında öğreticiler yetiştirmek amacıyla düzenlenen sertifika programlarını işleyişi ve içeriği açısından katılımcıların görüşleri aracılığıyla incelemeyi hedef alan bu çalışma var olan durumu tanımlamayı ve

Adres | Address

RumeliDE Dil ve Edebiyat Araşturmalar Dergisi $\quad$ RumeliDE Journal of Language and Literature Studies Osmanağa Mahallesi, Mürver Çiçeği Sokak, No:14/8 $\quad$ Osmanağa Mahallesi, Mürver Çiçeği Sokak, No:14/8 Kadıköy - ÍSTANBUL / TÜRKIYE 34714 Kadıköy - ISTANBUL / TURKEY 34714 e-posta: editor@rumelide.com e-mail: editor@rumelide.com, tel: +90 505 7958124, +90 2167730616 phone: +90 505 7958124, +90 2167730616 
daha sonra oluşturulacak programlar için ilkelerin belirlenmesini amaçlamıştır. Bu örnek alan çalışmasından hareketle sertifika programlarının öğretici kazanımları açısından değerlendirilmesi ile yabancı/ikinci dil olarak Türkçe öğretiminin öğretmen yetiştirme açısından niteliği tartışılacaktır.

\section{Yöntem}

Türkçenin yabancı dil olarak öğretilmesine yönelik öğretmen yetiştirme sertifika programının kursiyerlerin gözünden değerlendirilmesini amaçlayan bu araştırma yarı yapılandırılmış durum çalışması (case study) yöntemiyle gerçekleştirilmiştir. Yabancı dil olarak Türkçenin öğretimi sertifika programlarını hedef alan bu çalışma var olan durumu tanımlamayı ve daha sonra oluşturulacak programlar için ilkelerin belirlenmesini amaçlamıştır. Creswell (2013: 97), durum çalışmasıyla gerçek yaşam bağlamında sınırları belirlenmiş bir ya da birden çok sistem veya durumu ele almak ve derinlemesine bilgi sağlamak adına gözlem, görüşme, görsel-işitsel kayıt gibi araçlara başvurulduğunu, bu yolla ayrıntılı bir durum betimlemesi sağlandığını vurgulamıştır. Bu araştırmanın verileri Hitit Üniversitesi Türkçe Öğretimi Uygulama ve Araştırma Merkezi tarafından 18 Ocak-5 Şubat 2021 tarihleri arasında düzenlenen Yabancı Dil Olarak Türkçe Öğretimi Sertifika programına katılan kursiyerlere yöneltilen anket soruları aracıllğıyla görüşleri alınarak elde edilmiştir. Veri toplama aracı olarak 14 maddeden oluşan anket formu kullanılmıştır. Anket için alan yazın taraması yapılarak taslak hâli hazırlanmıştır. Yabancı dil olarak Türkçenin öğretimi ile ölçme değerlendirme alanında uzman üç öğretim elamanın görüşleri alındıktan sonra anketin son hâli oluşturulmuştur. Anketten toplanan verilerin sonuçları bulgular bölümünde tablo halinde sunularak nicel olarak değerlendirilmiştir. Kursiyerlerden edinilen izlenimlerden hareketle söz konusu kursun niteliğine yönelik yorumlara da yer verilmiştir. Sertifika programına katılan kursiyerlerin anketlere verdikleri yanıtlara göre görüşleri değerlendirilmiştir. Anket aracılığıyla elde edilen veriler, tablolara olduğu gibi yansıtılmış ve yorumlanmıştır. Aynı ya da benzer görüşü ifade edenlerin cevapları frekans değerlerine yansıtılmıştır. Toplanan veriler, frekans ve yüzde tabloları şeklinde sunulmuştur.

\section{Bulgular}

Çalışmada, Hitit Üniversitesi TÖMER tarafından düzenlenen yabancı dil olarak Türkçe öğretimi sertifika programına katılan 32 kişinin program ile ilgili beklentileriyle sertifika programı hakkındaki görüşlerine ilişkin bulgulara yer verilmiştir. Bu örnek alan çalışmasından hareketle sertifika programlarının öğretici kazanımları açısından değerlendirilmesi ile yabancı dil olarak Türkçe öğretiminin öğretmen yetiştirme açısından niteliği tartışlacaktır.

Tablo 1. Katılımcıların demografik bilgileri

\begin{tabular}{|c|c|c|c|}
\hline & & $\mathbf{N}$ & $\%$ \\
\hline Yaş aralığı & $21-25$ & 11 & 34,3 \\
\hline & $26-30$ & 12 & 37,5 \\
\hline & $31-35$ & 6 & 18,7 \\
\hline & $36-41+$ & 3 & 9,3 \\
\hline Cinsiyet & Kadın & 23 & 71,8 \\
\hline & Erkek & 9 & 28,1 \\
\hline Mezuniyet durumu & Lisans & 9 & 28,1 \\
\hline $\begin{array}{r}\text { RumeliDE } \\
\text { Osmanağa M } \\
\mathrm{K} \\
\text { te }\end{array}$ & $\begin{array}{r}\text { Adres } \\
\text { alar Dergisi } \\
\text { kak, No:14/8 } \\
\text { RKIYE } 34714 \\
\text { umelide.com } \\
1167730616\end{array}$ & $\begin{array}{l}\text { Address } \\
\text { RumeliDE Journal of Language an } \\
\text { Osmanağa Mahallesi, Mürver Ciçĕ } \\
\text { Kadıköy - ISTANBUL / TURKEY } 34 \\
\text { e-mail: editor@rumelide.com, } \\
\text { phone: +90 505 7958124, +90 } 216\end{array}$ & \\
\hline
\end{tabular}


A case study on the effectiveness of certificate programs in teaching Turkish as a foreign language / Z. C. Candaş; S. Başutku (pp. 158-170)

\begin{tabular}{|c|c|c|c|}
\hline & Lisans mezunu & 11 & 34,4 \\
\hline & Yüksek lisans & 8 & 25 \\
\hline & Doktora & 4 & 12,5 \\
\hline \multirow[t]{6}{*}{ Mezun olduğunuz/ olacağınız bölüm } & Türk dili ve edebiyatı & 17 & 53,1 \\
\hline & Türk dili ve edebiyatı öğretmenliği & 1 & 3,2 \\
\hline & Türkçe öğretmenliği & 3 & 9,3 \\
\hline & Filoloji & 3 & 9,3 \\
\hline & Çağdaş Türk Lehçeleri & 7 & 21,8 \\
\hline & Sinıf Öğretmenliği & 1 & 3,2 \\
\hline \multicolumn{2}{|l|}{ Toplam } & 32 & 100 \\
\hline
\end{tabular}

Hitit Üniversitesi Türkçe Öğretimi Uygulama ve Araştırma Merkezi tarafından 18 Ocak-5 Şubat tarihleri arasında düzenlenen Yabancı Dil Olarak Türkçe Öğretimi Sertifika Programına başvuran 32 öğretici adayının \%71,8 oranında 23 kişisi kadın, \%28,1 oranında 9 kişisi erkektir. 1. Tablo incelendiğinde katılımcıların yaş grupları 21-25 yaş arası $11(\% 34,3), 26-30$ yaş arası $12(\% 37,5), 31-35$ yaş arası 6 $(\% 18,7), \quad 36-41$ yaş arası 3 (\%9,3) şeklindedir. Katılımcıların 21-25; 26-30 yaş aralığında yoğunlaşmasının sebebi üniversite okumakta veya yeni mezun olup yabancı dil olarak Türkçe öğretimi alanında bilgi ve tecrübe sahibi olmak istemelerinden kaynaklanmaktadır. Bu çalışmaya katılan öğretici adaylarından 17 kişi $(\% 53,1)$ Türk dili ve edebiyatı, 7 kişi $(\% 21,8)$ çağdaş Türk lehçeleri, 3 kişi $(\% 9,3)$ Türkçe öğretmenliği, 3 kişi $(\% 9,3)$ filoloji, Türk dili ve edebiyatı ile sınıf öğretmenliği bölümlerinden 1'er kişi $(\% 3,2)$ olduğu gözlemlenmiştir. Katılımcıların mezuniyet durumlarına bakıldığında lisans mezunu 11 kişi $(\% 34,4)$. 26-30 yaş arası 12 (\%37,5), 31-35 yaş arası $6(\% 18,7), 36-41$ yaş arası $3(\% 9,3)$ şeklindedir. Katılımcıların 21-25; 26-30 yaş aralığında yoğunlaşmasının sebebi üniversite okumakta veya yeni mezun olup yabancı dil olarak Türkçe öğretimi alanında bilgi ve tecrübe sahibi olmak istemelerinden kaynaklanmaktadır. Bu çalışmaya katılan öğretici adaylarından 17 kişi (\%53,1) Türk dili ve edebiyat1, 7 kişi $(\% 21,8)$ çağdaş Türk lehçeleri, 3 kişi $(\% 9,3)$ Türkçe öğretmenliğii, 3 kişi $(\% 9,3)$ filoloji, Türk dili ve edebiyatı ile sınıf öğretmenliği bölümlerinden 1'er kişi $(\% 3,2)$ olduğu gözlemlenmiştir. Katılımcıların mezuniyet durumlarına bakıldığında lisans mezunu 11 kişi $(\% 34,4)$, lisans son sınıf öğrencisi 9 kişi $(\% 28,1)$, yüksek lisans 8 kişi $(\% 25)$, doktora yapan 4 kişi $(\% 12,5)$ olarak görülmektedir.

Tablo 2. Katılımcıların sertifika programına ilişkin beklentileri

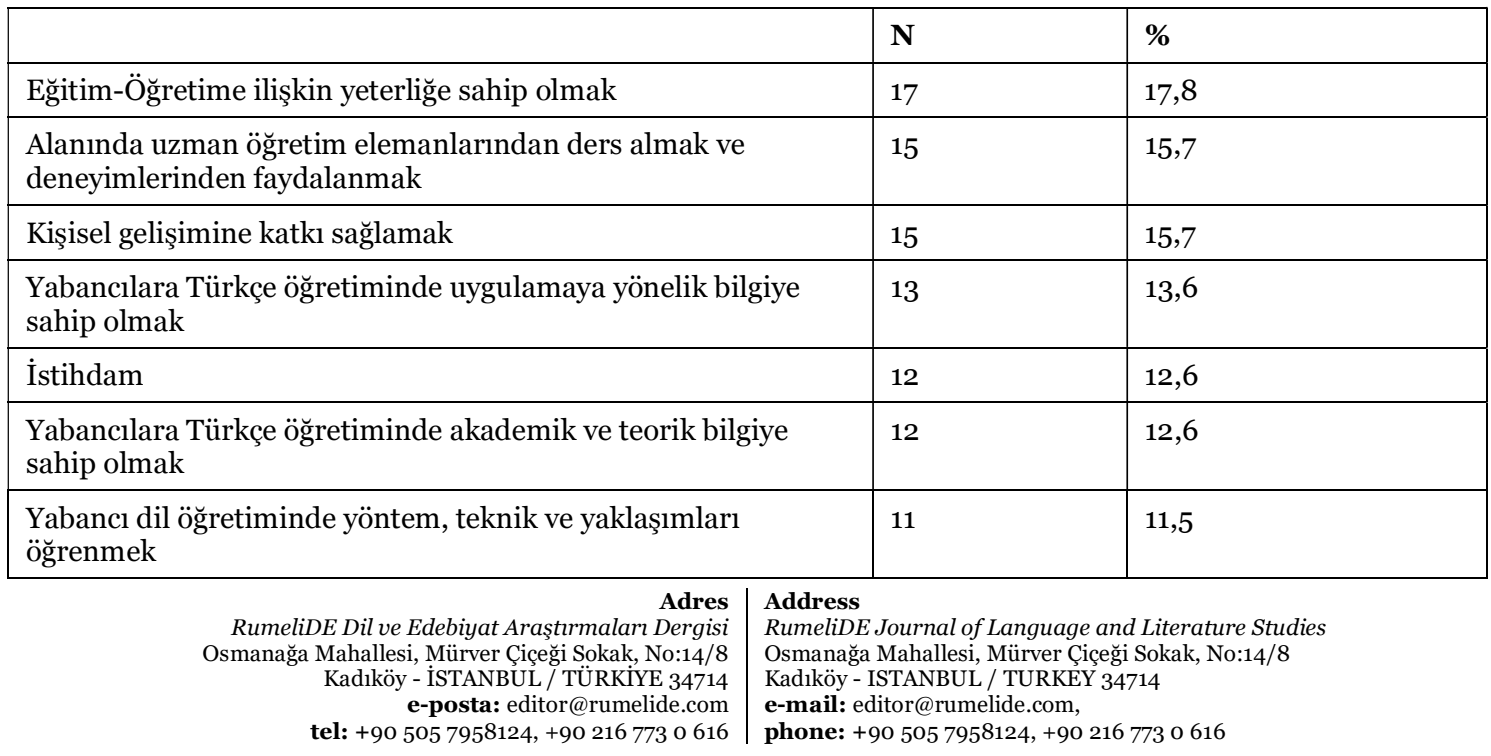




\begin{tabular}{|l|l|l|}
\hline Toplam & 95 & 100 \\
\hline
\end{tabular}

Tablo 2'de katılımcıların sertifika programına ilişkin beklentilerine bakıldığında \%17,8 oranıyla "eğitimöğretime ilişkin yeterliliğe sahip olmak” görüşü olduğu gözlemlenmiştir. Devamında katılımcılar \%15,7 oranında "alanında uzman öğretim elemanlarından ders almak ve deneyimlerinden faydalanmak" görüşü yer almıştır. Aynı oranda katılımcıların "kişisel gelişimine katkı sağlamak” görüşünün olduğu tespit edilmiştir. Katılımcılar sırasıyla \%13,6 oranında "yabancılara Türkçe öğretiminde uygulamaya yönelik bilgiye sahip olmak", "istihdam” ve ardından "yabancılara Türkçe öğretiminde akademik ve teorik bilgiye sahip olmak" görüşünü \%12,6 oranında belirtmişlerdir. Katılımcıların, "yabancı dil öğretiminde yöntem, teknik ve yaklaşımları öğrenmek” görüşü \%11,5 oranında belirlenmiştir.

Tablo 2'de belirlenen verilerin sonucuna göre katılımcıların beklentilerine ilişkin görüşlerinde yüksek gereksinim olarak eğitim-öğretime ilişkin yeterliliğe sahip olma ile alanında uzman hocalardan ders almak ve deneyimlerinden faydalanmak gereksinimin yüksek olduğu görülmektedir. Bu duruma ek olarak katılımcıların dil öğretim yaklaşım, yöntem ve teknikleri öğrenmeyi temel hedef aldıkları da belirlenmiştir. Alanda çalışan deneyimli öğretim elemanlarından ders alarak tecrübelerinden yararlanmanın önemli olduğu vurgulanmaktadır

Katılımcıların görüşlerine göre Türkçeyi yabancı dil olarak öğrenenlerin düzeyine uygun sınıf içi etkinliklerin düzenlenmesinde ve etkili iletişimin sağlanmasına yönelik kaygılarının olduğu belirlenmiştir. Sertifika programına katılan 17 kişi (\% 53,1) Türk dili ve edebiyatı, 7 kişi $(\% 21,8)$ çağdaş Türk lehçeleri bölümlerinden mezun veya mezun olacaktır. Bu yüzden programa katılan çoğunluğun eğitim bilimlerine dair alan bilgisine sahip olmaması nedeniyle katılımcllar alanında uzman öğreticilerin bilgi ve deneyimlerine uygun öğretim yöntem ve tekniklerinin sınıf içinde nasıl kullanılacağını bilmek istemiştir. Bu durum akademik yeterliliğin yanında uygulamaya yönelik bilgiye ihtiyacın yüksek olduğu sonucuna ulaştırmıştır.

Tablo 3. Katılımcıların sertifika sahibi olmaya ilişkin görüşleri

\begin{tabular}{|l|l|l|}
\hline & $\mathbf{N}$ & $\mathbf{\%}$ \\
\hline İstihdam & 9 & 28,1 \\
\hline Mesleki gelişim & 9 & 28,1 \\
\hline Kişisel gelişim & 8 & 25 \\
\hline $\begin{array}{l}\text { Türkçe öğretimine katkıda bulunarak yaygınlığını ve } \\
\text { bilinirliğini artırmak }\end{array}$ & 6 & 18,7 \\
\hline Toplam & 32 & 100 \\
\hline
\end{tabular}

Katılımcıların niçin yabancılara Türkçe öğretimi sertifikasına sahip olmak istediklerine ilişkin görüşlerinde 9 kişi \%28,1 oranında "istihdam" ve "mesleki gelişim” başlıkları altında eşit oranla sertifika alma nedenlerini belirtmişlerdir. Katılımcılardan 8 kişi \%25 oranında kişisel gelişim amacıyla katılırken 6 kişi de \%18,7 oranında Türkçe öğretimine katkıda bulunarak yaygınlı̆̆ını ve bilinirliğini arttırmak amacıyla katıldıklarını belirtmişlerdir.

Verilerin değerlendirilmesinden çıan sonuçlara göre hem Yabancı dil olarak Türkçe öğretimine yönelik lisans ve öğretmen yetiştirme programlarının olmaması hem de kursiyerlerin istihdam ve mesleki gelişim kaygıları nedeniyle sertifika programına katılmak istemektedirler.

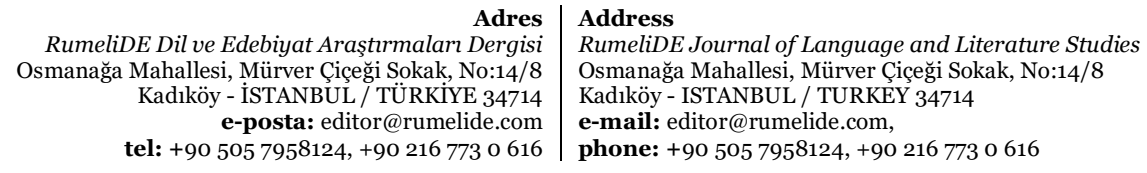


164 / RumeliDE Journal of Language and Literature Studies 2021.Ö10 (October)

A case study on the effectiveness of certificate programs in teaching Turkish as a foreign language / Z. C. Candaş; S. Başutku (pp. 158-170)

Tablo 4. Katılımcıların kendilerini yeterli bulmadıkları alan konularına ilişkin belirlemeleri

\begin{tabular}{|l|l|l|}
\hline & N & \% \\
\hline Öğretim yöntem, teknik ve yaklaşımlar & 8 & 17,3 \\
\hline Alanı hiç bilmediğinden eksikliklerini tanımlayamayanlar & 7 & 15,2 \\
\hline Sinıf deneyimi & 7 & 15,2 \\
\hline Pedagojik alan bilgisi & 5 & 10,8 \\
\hline Materyal üretimi & 5 & 10,8 \\
\hline İletişim kurma becerisi & 4 & 8,6 \\
\hline Dilbilgisi öğretimi & 3 & 6,5 \\
\hline Yazılı ve sözlü dili doğru kullanabilme & 2 & 4,3 \\
\hline Ölçme ve değerlendirme & 2 & 4,3 \\
\hline Hedef kitlenin anadilini bilmek & 2 & 4,3 \\
\hline Sözcük öğretimi & 1 & 2,1 \\
\hline Toplam & 46 & 100 \\
\hline
\end{tabular}

Tablo 4’teki verilere bakıldığında katılımcıların "Yabancı dil olarak Türkçe öğretimi alanında kendinizde eksik olduğunu düşündüğünüz konular neler?” sorusuna ilişkin görüşlerine yer verilmiştir. Verilerden elde edilen sonuçlara göre katılımcıların çoğunluğu "öğretim yöntem, teknik ve yaklaşımlar” başlı̆̆ altında $8(\% 17,3)$ oranında görüsş bildirmektedir. Bu sayıyı sırasıyla 7 (\%15,2) görüş ile "alanı hiç bilmediğinden eksiklerini tanımlayamayanlar" ve "sınıf deneyimine sahip olmayanlar" takip etmektedir. Verilere göre "Pedagojik alan bilgisi ve materyal üretimi” görüşleri $5(\% 10,8)$ oranında temsil edilmiştir.

Tabloya göre sertifika programında yer alan katılımcılar daha çok Yabancılara Türkçe Öğretimi alanında uygulama ve tecrübe yönüyle kendilerini eksik bulduklarını belirtmişlerdir. Tabloda belirtilen verilere göre programa katılan öğretici adaylarının Yabancı dil olarak Türkçe öğretimine yönelik derslerde kullanılabilecek yöntem ve tekniklere ilişkin kendilerini eksik hissetmeleri dil öğretimi kapsamında var olan yöntem ve teknikleri nasıl uygulayacakları konusunda bilgi sahibi olmamalarına bağlanabilir. Öğretim yöntem ve tekniklerini yabancı dil öğretiminde etkili bir şekilde kullanmak öğrencinin derse ilgisini çekip eğitim sürecine katılımını sağlama, kaygısını azaltma ve yaratıcı yeteneklerinin ortaya çıartılabilmesi açısından önem arz eder. Bu duruma ek olarak öğretici adaylarının temel düzeyden ileri düzeye kadar öğrencilere bir konuyu nasıl ve ne zaman öğreteceğini bilmemesiyle birlikte yabancı dil olarak Türkçe öğretiminin anadili Türkçe öğretiminden oldukça farklı olması gibi nedenler yabancı dil olarak Türkçe öğretimi konusunda kendilerini yetersiz hissetmelerine yönelik verilerin yüksek çlkmasına sebep olmuştur.

Tablo 5. Katılımcıların sertifika programının içeriğine ilişkin görüşleri

\begin{tabular}{|l|l|l|}
\hline & $\mathrm{N}$ & $\%$ \\
\hline Ders çeşitliliğinin yeterliği & 14 & 43,7 \\
\hline Alanında uzman isimlere yer verilmiş olması & 12 & 37,5 \\
\hline Kişisel ve mesleki gelişime katkı sağlaması & 3 & 9,3 \\
\hline Görüşü olmayanlar & 3 & 9,3 \\
\hline Toplam & 32 & 100 \\
\hline
\end{tabular}

Adres

RumeliDE Dil ve Edebiyat Araşturmaları Dergisi Osmanağa Mahallesi, Mürver Çiçeği Sokak, No:14/8 Kadıköy - İSTANBUL / TÜRKIYE 34714 e-posta: editor@rumelide.com tel: +90 $5057958124,+902167730616$
Address

RumeliDE Journal of Language and Literature Studies

Osmanağa Mahallesi, Mürver Çiçeği Sokak, No:14/8

Kadıköy - ISTANBUL / TURKEY 34714

e-mail: editor@rumelide.com,

phone: +90 5057958124, +90 2167730616 
Katılımcıların sertifika programının içeriği hakkındaki görüşlerine ilişkin bulgularda $14(\% 43,7)$ "ders çeşitliliğini” yeterli buldukları tespit edilmiştir. $\mathrm{Bu}$ oran katılımcıların sertifika programından beklentilerini karşıladığını göstermektedir.12 $(\% 37,5)$ katılımcı "alanında uzman isimlere yer verilmiş" olması nedeniyle tercih etmiştir. $3(\% 9,3)$ katılımcı ise "kişisel ve mesleki gelişime katkı sağlaması" olarak görüş bildirmiştir. Programla ilgili görüşü olmayanlarda 3 kişi $(9,3)$ olarak tespit edilmiştir.

Tablo 6. Katılımcıların sertifika programının süresine ilişkin görüşleri

\begin{tabular}{|l|l|l|}
\hline & $\mathbf{N}$ & $\mathbf{\%}$ \\
\hline Yeterli & 22 & 68,7 \\
\hline Kisa & 8 & 25 \\
\hline Uzun & 2 & 6,2 \\
\hline Toplam & 32 & 100 \\
\hline
\end{tabular}

Tablo 6'da katılımcıların sertifika programının süresine ilişkin görüşlerine yer verilmiştir. Katılımcılardan 22' si $(\% 68,7)$ yeterli olduğunu, 8 katılımcı $(\% 25)$ kısa olduğunu, 2 katılımcı $(\% 6,2)$ da uzun olduğunu ifade etmiştir.

Tablo 7. Katılımcıların Sertifika programının içeriğine ilişkin görüşleri

\begin{tabular}{|l|l|l|}
\hline Katılımcların görüşleri & $\mathbf{N}$ & $\mathbf{\%}$ \\
\hline Uygulama & 15 & 46,8 \\
\hline Her ikisi & 10 & 31,2 \\
\hline Kuramsal & 7 & 21,8 \\
\hline Toplam & 32 & 100 \\
\hline
\end{tabular}

Katılımcllara yöneltilen "Sertifika programında kuramsal bilgiler bölümü mü yoksa uygulama bölümü mü daha önemli?" sorusuna 15 katılımcı $(\% 46,8)$ "uygulama” yanıtını verirken 10 katılımcı $(31,2)$ "her ikisi” 7 katılımcı $(\% 21,8)$ “kuramsal” yanıtını vermiştir.

Tablo 8. Katılımcıların sertifika programındaki ders içeriklerinin kendilerine katkılarına ilişkin görüşleri

\begin{tabular}{|c|c|c|}
\hline & $\mathbf{N}$ & $\%$ \\
\hline YTÖ’de yaklaşım, yöntem ve teknikler & 9 & 19,1 \\
\hline 4 temel dil becerisi & 7 & 14,8 \\
\hline Uygulama & 7 & 14,8 \\
\hline İlk ders & 4 & 8,5 \\
\hline Öğretici yeterlilikleri & 3 & 6,3 \\
\hline YTÖ’nün İncelikleri ve esasları & 3 & 6,3 \\
\hline Beden dili & 3 & 6,3 \\
\hline Web araçları & 3 & 6,3 \\
\hline Dil bilgisi & 2 & 4,2 \\
\hline YTÖ'de temel kavramlar & 2 & 4,2 \\
\hline Ölçme ve değerlendirme & 1 & 2,1 \\
\hline Kültürlerarası etkileşim & 1 & 2,1 \\
\hline Materyal tasarımı & 1 & 2,1 \\
\hline 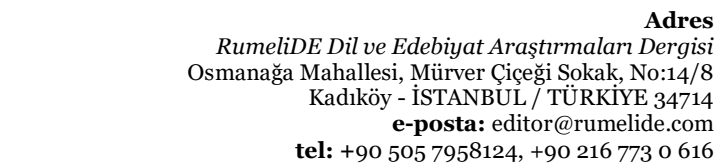 & $\begin{array}{l}\text { Address } \\
\text { RumeliDE Journal } \\
\text { Osmanağa Mahalles } \\
\text { Kadköy - ISTANBU } \\
\text { e-mail: editor@rur } \\
\text { phone: +90 505 79 }\end{array}$ & $\begin{array}{l}\text { ature Studies } \\
\text {, No:14/8 } \\
616\end{array}$ \\
\hline
\end{tabular}


166 / RumeliDE Journal of Language and Literature Studies 2021.Ö10 (October)

A case study on the effectiveness of certificate programs in teaching Turkish as a foreign language / Z. C. Candaş; S. Başutku (pp. 158-170)

\begin{tabular}{|l|l|l|}
\hline DİAOÖÇ (CEFR) & 1 & 2,1 \\
\hline Toplam & 47 & 100 \\
\hline
\end{tabular}

Tablo 8'e bakıldığında katılımcıların "Sertifika programında hangi dersin daha fazla katkı sağlayacağını düşünüyorsunuz?” sorusuna verdikleri cevaplar gruplandırıldığında 9 (\%19,1) görüş ile en fazla “YTÖ’de yaklaşım, yöntem ve teknikler" başlığına yer verildiği görülmektedir. Katılımcılar $7(\% 14,8)$ görüş ile "4 temel dil becerisi ile uygulama" derslerinin daha fazla katkı sağladığını düşünmektedirler. "ìlk ders” başlığı da $4(\% 8,5)$ görüş tarafından ifade edilmiştir.

Tablo 9. Katılımcıların Yabancı dil olarak Türkçe öğretiminin önemine ilişkin görüşleri

\begin{tabular}{|l|l|l|}
\hline & N & \% \\
\hline Türkiye'yi, Türk kültürünü ve dilini tanıtmak & 16 & 31,3 \\
\hline Türkçenin konuşulduğu coğrafyanın genişlemesi & 8 & 15,6 \\
\hline Türkiye’ye gelen düzensiz göçmenlerin uyum sağlamaları & 7 & 13,7 \\
\hline Türkçenin evrensel bir dil olması & 6 & 11,7 \\
\hline Türkiye'nin sosyokültürel ve sosyoekonomik açıdan önemi & 6 & 11,7 \\
\hline Türkiye'nin konumu nedeniyle cazibe merkezi olması & 4 & 7,8 \\
\hline Öğrenilmesi kolay bir dil & 4 & 7,8 \\
\hline Toplam & 51 & 100 \\
\hline
\end{tabular}

Tablo 9'da katılımcıların "Yabancı dil olarak Türkçe öğretimi niçin önemlidir?" soruna ilişkin görüşlerine yer verilmiştir. Katılımclların büyük bir çoğunluğu bu soruya $16(\% 31,3)$ görüş ile "Türkiye'yi, Türk kültürünü ve dilini tanıtmak" başlı̆̆ı altında cevaplar vermişlerdir.8 $(\% 15,6)$ görüş "Türkçenin konuşulduğu coğrafyanın genişlemesi” olarak belirtirken, 7 (\%13,7) görüş "Türkiye'ye gelen düzensiz göçmenlerin uyum sağlamaları" olarak değerlendirmektedir.

Tablo 1o. Katılımcıların yabancılara Türkçe öğretiminde kendilerini geliştirmek istedikleri alanlara ilişkin belirlemeleri

\begin{tabular}{|l|l|l|}
\hline & N & $\%$ \\
\hline Öğretim yöntem ve teknikleri & 22 & 55 \\
\hline Temsil yeteneği ve iletişim becerileri & 6 & 15 \\
\hline Teknoloji kullanımı & 4 & 10 \\
\hline İkinci dil bilmek & 3 & 7,5 \\
\hline Ölçme ve değerlendirme & 3 & 7,5 \\
\hline Yazılı ve sözlü dili doğru kullanabilme & 1 & 2,5 \\
\hline Materyal tasarımı & 1 & 2,5 \\
\hline Toplam & 1 & 100 \\
\hline
\end{tabular}

Tablo 10'daki verilerin değerlendirilmesine göre "Yabancılara Türkçe öğretimi alanında kendinizde geliştirmeyi düşündüğünüz yönler nelerdir?” sorusuna 22 (\%55) “öğretim yöntem ve tekniğe ilişkin yeterliliğe sahip olma" yanıtı verilmiştir. İkinci sırada 6 görüş (\%15) ile "temsil yeteneği ve iletişim becerilerini” geliştirmek olmuştur. "teknoloji kullanımı” yanıtı 4 (\%10) görüşle temsil edilirken 3’er görüşle $(\% 7,5)$ "ikinci dil bilmek", “ölçme ve değerlendirme” temsil edildiği gözlemlenmiştir. Son olarak 1 görüş $(\% 2,5)$ "Yazılı ve sözlü dili doğru kullanabilme" olarak tespit edilmiştir.

\section{Adres | Address}

RumeliDE Dil ve Edebiyat Araşturmalar Dergisi $\quad$ RumeliDE Journal of Language and Literature Studies Osmanağa Mahallesi, Mürver Çiçeği Sokak, No:14/8 Osmanağa Mahallesi, Mürver Çiçeği Sokak, No:14/8 Kadıköy - İSTANBUL / TÜRKIYE 34714 Kadıköy - ISTANBUL / TURKEY 34714 e-posta: editor@rumelide.com e-mail: editor@rumelide.com, tel: +90 505 7958124, +90 2167730616 phone: +90 505 7958124, +90 2167730616 
Tablo 11. Katılımcıların Yabancılara Türkçe öğretiminde kullanılacak etkinliklere ilişkin görüşleri

\begin{tabular}{|l|l|l|}
\hline & N & \% \\
\hline Görsel ve işitsel etkinlikler & 12 & 27,9 \\
\hline Kültürel etkileşim etkinlikleri & 10 & 23,2 \\
\hline Canlandırma ve oyun etkinlikleri & 9 & 20,9 \\
\hline Ders dışı etkinlikler & 5 & 11,6 \\
\hline Bilgisayar tabanlı etkinlikler & 4 & 9,3 \\
\hline Soru, cevap, tartı̧ma türleri & 2 & 4,6 \\
\hline Bireysel farklılıklara göre etkinlik tasarlama & 1 & 2,3 \\
\hline Toplam & 43 & 100 \\
\hline
\end{tabular}

Tablo 11’e bakıldığında katılımcıların "Yabancılara Türkçe öğretiminde öğrencilere yönelik Türkçeyi etkin kullanmak adına ne tür etkinlikler düzenlenmelidir?” sorusuna verdikleri cevaplar ele alınmaktadır. Verilerin değerlendirilmesine göre "görsel ve işitsel etkinlikler" 12 görüşüle $(\% 27,9)$ oranında birinci sırada yer almaktadır. İkinci sırada $10(\% 23,2)$ kültürel etkileşim olduğu tespit edilirken $9(\% 11,6)$ canlandırma ve oyun etkinlikleri üçüncü sırada yer almıştır. Bu sırayı $5(\% 11,6)$ görüş ile ders dışı etkinlikler takip etmektedir. Görsel ve işitsel etkinliklerin birinci sırada yer alması gerek sınıf ortamında gerekse uzaktan eğitimde olsun görsel ve işitsel etkinliklerin kullanımı üzerinde durulduğu için katılımcıların bu durumun önemini kavradıklarını göstermektedir.

Tablo 12. Katılımcıların yabancılara Türkçe öğretim alanında yaklaşım, yöntem ve tekniklere ilişkin görüşler

\begin{tabular}{|l|l|l|}
\hline & $\mathrm{N}$ & $\%$ \\
\hline İletişimsel yöntem & 10 & 27 \\
\hline Post-metod & 8 & 21,6 \\
\hline İşitsel dilsel yöntem & 6 & 16,2 \\
\hline Seçmeli yöntem & 4 & 10,8 \\
\hline Bilişsel yaklaşım & 3 & 8,1 \\
\hline Doğal yaklaşım & 3 & 8,1 \\
\hline Doğrudan yöntem & 2 & 5,4 \\
\hline Toplu fiziksel tepki yöntemi & 1 & 2,7 \\
\hline Toplam & 37 & 100 \\
\hline
\end{tabular}

Katılımcıların "Yabancılara Türkçe öğretim alanında hangi yaklaşım, yöntem ve teknikleri kullanılmalıdır?" sorusuna en fazla 10 (\%27) görüş ile "iletişimsel yöntem” cevabını vermişlerdir.8 $(\% 21,6)$ görüş "post-metod" cevabını verirken $6(\% 16,2)$ görüş "işitsel dilsel yöntem”, $4(\% 10,8)$ görüş "seçmeci yöntem", $3(\% 8,1)$ görüş "bilişsel yaklaşım ve doğal yaklaşım”, $2(\% 5,4)$ görüş "doğrudan yöntem” ve $1(\% 2,7)$ görüş "toplu fiziksel tepki yöntemi” olarak tespit edilmiştir.

Tablo 13. Katılımcıların Yabancı dil Olarak Türkçe öğreticilerinde bulunması gereken özelliklere ilişkin görüşleri

\begin{tabular}{|c|c|c|}
\hline & $\mathbf{N}$ & $\%$ \\
\hline Mesleki yeterlilik (alan bilgisi) & 13 & 18 \\
\hline Sabır & 9 & 12,5 \\
\hline Heyecan (meslek sevgisi) & 8 & 11,1 \\
\hline $\begin{array}{r}\text { Adres } \\
\text { RumeliDE Dil ve Edebiyat Araştrrmaları Dergisi } \\
\text { Osmanağa Mahallesi, Mürver Ciçeği Sokak, No:14/8 } \\
\text { Kadıköy - İSTANBUL / TÜRKIYY } 34714 \\
\text { e-posta: editor@rumelide.com } \\
\text { tel: +90 505 7958124, +90 } 2167730616\end{array}$ & \multicolumn{2}{|c|}{$\begin{array}{l}\text { Adaress } \\
\text { RumeliDE Journal of Language and Literature Studies } \\
\text { Osmanağa Mahallesi, Mürver Çiçeği Sokak, No:14/8 } \\
\text { Kadlköy - ISTANBUL / TURKEY } 34714 \\
\text { e-mail: editor@rumelide.com, } \\
\text { phone: +90 505 7958124, +90 } 216773 \text { o } 616\end{array}$} \\
\hline
\end{tabular}


168 / RumeliDE Journal of Language and Literature Studies 2021.Ö10 (October)

A case study on the effectiveness of certificate programs in teaching Turkish as a foreign language / Z. C. Candaş; S. Başutku (pp. 158-170)

\begin{tabular}{|l|l|l|}
\hline Telaffuz & 7 & 9,7 \\
\hline Etkili iletişim & 7 & 9,7 \\
\hline Hoşgörü & 6 & 8,3 \\
\hline Tecrübe & 6 & 8,3 \\
\hline Kişisel gelişime önem verme & 5 & 6,9 \\
\hline Teknolojik yeterlilik & 3 & 4,1 \\
\hline Ders araç gereçlerini geliştirme & 3 & 4,1 \\
\hline Kültürel farkındalık & 3 & 4,1 \\
\hline Beden dili kullanımı & 2 & 2,7 \\
\hline Toplam & 72 & 100 \\
\hline
\end{tabular}

Tablo 13'deki veriler incelendiğinde katılımcıların "Yabancı Dil Olarak Türkçe öğreticilerinde bulunması gereken özellikler nelerdir?” sorusuna ilişkin görüşlerine yer verilmiştir.13 (\%18) görüş “mesleki yeterlilik" cevabı verirken, 9 (\%12,5) görüş "sabır", 8 (\%11,1) görüş "heyecan”, $7(\% 9,7)$ görüş "telaffuz ve etkili iletişim", $6(\% 8,3)$ görüş "hoşgörü ve tecrübe", $5(\% 6,9)$ görüş "kişisel gelişime önem verme", 3 $(\% 4,1)$ görüş “teknolojik yeterlilik, materyal geliştirme ve kültürel farkındalı", 2(\%2,7) görüş de "beden dili kullanımı” olarak tespit edilmiştir.

Tablo 14. Katılımcıların Yabancı Dil Olarak Türkçe Öğretimi Sertifika Programı kapsamında aldıkları derslere ilişkin görüşleri

\begin{tabular}{|l|l|l|}
\hline & $\mathbf{N}$ & $\mathbf{\%}$ \\
\hline Uygulama derslerinin verimli olması & 14 & 28 \\
\hline Kuramsal derslerin düzeyin üstü olması & 10 & 20 \\
\hline Ders içeriklerinin yeterli olması & 8 & 16 \\
\hline Alanında uzman öğretim elemanlarından ders alınması & 7 & 14 \\
\hline YTÖ alanıyla ilgili farkındalık oluşturması & 4 & 8 \\
\hline Ders içeriklerinin çeşitli olması & 4 & 8 \\
\hline Ders saatlerinin yeterli olması & 3 & 6 \\
\hline Toplam & 50 & 100 \\
\hline
\end{tabular}

Tablo 14'e bakıldığında katılımcıların "Yabancı Dil Olarak Türkçe Öğretimi Sertifika Programı kapsamında verilen derslerin değerlendirilmesi” ne ilişkin görüşlerine yer verilmiştir. Tabloda belirtilen verilere göre katılımcllardan "uygulama derslerinin verimli olması" 14 (\%28) görüş olarak belirlenmiştir. Bu görüşü ikinci sırada 10 (\%20) "kuramsak derslerin düzey üstü olması” takip etmiştir. Verilerden elde edilen sonuçlara göre üçüncü sırada 8 (\%16) görüşle "ders içeriklerinin yeterli olması" gözlemlenirken dördüncü sırada 7 (\%14) alanında uzman öğretim elemanlarından ders alınması görüşü yer almıştır. Son olarak "YTÖ alanıyla ilgili farkındalık oluşturması" ve "ders içeriklerinin çeşitli olması" 4 (\%8) görüşleri ile "ders saatlerinin yeterli olması" görüşü 3(\%6) oranında tespit edilmiştir.

Verilerden elde edilen sonuçlar bazı katılımcıların henüz mezun olmamasından dolayı art alan bilgilerinin eksikliğini ve son sınıf bilgilerinin yeterli olmadığını göstermektedir. Ayrıca veriler incelendiğinde, katılımcıların çoğunluğunun Türk Dili ve Edebiyatı ile Çağdaş Türk Lehçeleri bölümlerinden mezun olmuş veya son sınıf öğrencileri olmaları ve programda verilen teorik bilgilerin

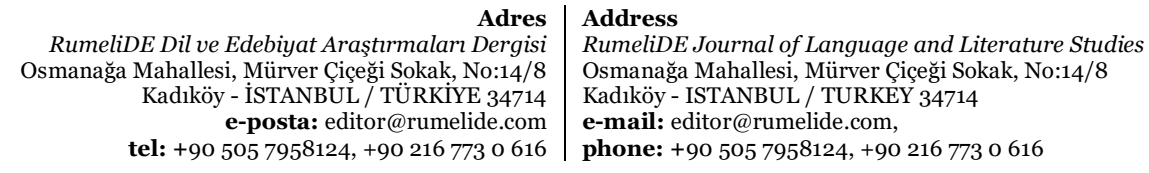


eğitim bilimleri alanıyla ilgili olması derslerde seviye üstü ya da üst düzey bilgiye yer verildiğine dair görüş bildirmelerine sebep olmuştur.

\section{Sonuç ve öneriler}

Yabancı Dil Olarak Türkçe Öğreticiliği için sertifika programına devam eden katılımcılar; dil öğretimine ve yabancı dil öğretim yöntem ve tekniklerine ilişkin gereksinimlerini çok açık bicimde dile getirmişlerdir. Dil öğretimi özel yöntemleri ve teknikleri içerdiği için çoğu katılımcı bu tanımlamayı yapmakta güçlük çekse de çeşitli biçimlerde Türkçenin yabancı dil olarak öğretimi özel alan bilgisinin önemini vurgulamışlardır. Çoğu katılımcı dil öğretim veya yabancı bölümlerinden mezun olmamasına rağmen yabancı dil olarak Türkçenin öğretiminin özel ve ayrıcalıklı bir Türkçe eğitimi ve öğretimi alanı olduğu farkındalığına varmış olduğu görülmektedir.

Dil ile ilgili bir bölümden mezun olmakla dil öğretimiyle ilgili bir bölümden mezun olmak farklı nitelikleri içerdiği için doğal olarak kurs katılımcılarının farklı gereksinimleri olduğu belirlenmiştir. Kurs süresi ve kapsamı tartışılması gereken bir konudur. Ayrıca ele alınmalıdır. Kursun en güçlü yanı uygulama ders saatlerinin çok etkin biçimde kullanılmış olmasıdır. Deneyimli eğitmenlerin derslerini izleme olanağı ve ders sunumlarına ve dönütlere ayrıntılı yer verilmiş olması kursiyerler tarafından çok olumlu olarak değerlendirilmiş ve öğrenmelerine katkı sağladı̆̆ını belirtmişlerdir. Kursun en zayıf yönü ise farklı eğitim geçmişine sahip öğretici adaylarının aynı sürede ve aynı kurs programıyla eğitim vermeye çalışılması olarak gözlemlenmiştir. Bu çalışmada öğretici adaylarının Türkçenin yapısal özelliklerini bildikleri varsayılmıştır. Türkçenin sesletim, biçimbilim, cümle yapısı ve anlam bilgisine ilişkin bilgi sahibi olmak ve bu bilgiyi öğrenenlerin düzeylerine göre düzenleyebilmek yabancı dil olarak Türkçenin öğretiminde önemli ve temel yeterliklerdir. Kursa devam eden öğreticilerin bu yeterliklere sahip olup olmadıkları belirlenmemiştir.

T.C. Milli Eğitim Bakanlı̆̆ Öğretmen Yetiştirme Genel Müdürlüğü, Talim ve Terbiye Kurulu Başkanlığı ve Dış İlişkiler Genel Müdürlüğü Projeler Koordinasyon Merkezi Başkanlığı işbirliğiyle o6-o8 Haziran 2010 tarihleri arasında düzenlenen çalıştayda Üniversitelerin ilgili bölümlerinden katılımcılarla geniş kapsamlı olarak yabancı dil olarak Türkçe öğretmeni yeterliği konusu incelenmiş ve yakın ve uzun vadede yapılması gerekenler belirlenmiştir.

Çalıştayda yabancı dil olarak Türkçe öğreticileri özel alan yeterliği ve öğretmen yetiştirme konuları incelenerek öneriler bir kitapçıkta toparlanmıştır, Bu çalışmanın bulguları ve önerileri de göz önünde bulundurularak değerlendirmeler yapılmalıdır.

\section{Kaynakça}

Açı, F. (2008). Türkiye'de yabancılara Türkçe öğretilirken karşılaşılan sorunlar ve çözüm önerileri. Doğu Akdeniz Üniversitesi Uluslararası Türkçe Eğitimi ve Öğretimi Sempozyumu.

Alyılmaz, C. (2010). Türkçe öğretiminin sorunları. Turkish Studies, S. 5(3), s. 728-749.

Barın, E., Çangal, Ö., Başar, U. (2017). Yabancı dil olarak Türkçe öğretimi alanında görev yapacak öğretmenlerin özel alan yeterliklerine ilişkin bir öneri. International Journal of Language Academy. 5 .

Boylu, E., Başar, U. (2016). Türkçe öğretim merkezlerinin güncel durumu ve standartlaştırılması üzerine. Akademik Sosyal Araştırmalar Dergisi. Yıl: 4, Sayı: 24, Mart 2016, s. 309-324.

Bulut, S. (2020). Türkçenin yabancı dil olarak öğretimi sertifika programının kursiyerlerin gözünden değerlendirilmesi. Journal of Language Education and Research. 6(2), 376-392.

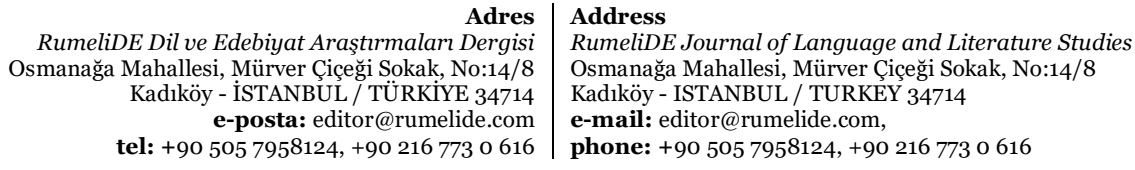


Creswell, J. (2013). Nitel araştırma yöntemleri, beş yaklaşıma göre nitel araştırma ve araştırma deseni (3. Baskıdan Çeviri). Mesut Bütün, Selçuk Beşir Demir (Çev. Ed.). Ankara: Siyasal Kitabevi.

Çelik, M. E. (2021). Düzenleyen görüşlerinden hareketle yabancılara Türkçe öğretimi sertifika programlarının incelenmesi. Karadeniz Araştırmaları. XVIII/70: 469-485.

Demir, T. (2021). Türkçe öğretmenlerinin/öğreticilerinin eğitimi ve pedagojik yeterlikleri üzerine bir değerlendirme. Ana Dili Ĕ̆itimi Dergisi. 9 (3) , 966-977.

Durmuş, M. (2013). Türkçenin yabancılara öğretimi: sorunlar, çözüm önerileri ve yabancılara Türkçe öğretiminin geleceğiyle ilgili görüssler. Adıyaman Üniversitesi Sosyal Bilimler Enstitüsü Dergisi Türkçenin Ĕ̆itimi Öğretimi Özel Sayısı. 11(6), s. 208-228.

Er, O., Biçer, N., Bozkırl, K. Ç. (2012). Yabancılara Türkçe öğretiminde karşılaşılan sorunların ilgili alan yazını ışığında değerlendirilmesi. Uluslararası Türkçe Edebiyat Kültür Eğitim (TEKE) Dergisi. S. 1(2), s. 51-69.

Kalenderoğlu, İ. (2019). Yabancı dil olarak Türkçe öğretiminde Türkiye’deki dil öğretim merkezlerinin durumu ve akreditasyon önerisi. XI. Uluslararası Dünya Dili Türkçe Sempozyumu Bildiri Kitabı, s. 1207-1215. Samsun.

Karababa, C. Z. (2010). Türkçenin yabancı dil olarak öğretimi ve bu alan için öğretmen yetiştirmenin önemi ve gereği. Yabancı Dil Olarak Türkçe Öğretimi ve Öğretmenliği Çalıştay Kitabı. Ankara: Promeda Yayınları.

Karababa, C. Z. (2009). Yabancı dil olarak Türkçenin öğretimi ve karşlaşılan sorunlar. Ankara Üniversitesi Eğitim Bilimleri Fakültesi Dergisi. S. 2. 265-277.

Güzel, A. (2003). Türkçe'nin eğitimi-öğretimi bölümlerinde kurulması gerekli görülen anabilim dalları hakkında yeni projelerimiz. Selçuk Üniversitesi Türkiyat Araştırmaları Dergisi. S. 13., 63-86.

Kara, M. (2010). Gazi Üniversitesi TÖMER öğrencilerinin Türkçe öğrenirken karşılaştıkları sorunlar ve bunların çözümüne yönelik öneriler. Gazi Üniversitesi Türk Eğitim Bilimleri Dergisi. S. 3. 661696.

Kurt, B. (2020) Yabancı dil olarak Türkçe öğretimi sertifika programına ilişkin kursiyer görüşlerinin karşılaştırmalı bir analizi. Akdeniz Üniversitesi Eğitim Fakültesi Dergisi. III/1: 73-90.

RumeliDE Dil ve Edebiyat Araşttrmaları Dergisi Osmanağa Mahallesi, Mürver Çiçeği Sokak, No:14/8 Kadıköy - İSTANBUL / TÜRKIYE 34714 e-posta: editor@rumelide.com tel: +90 $5057958124,+902167730616$
Address

RumeliDE Journal of Language and Literature Studies

Osmanağa Mahallesi, Mürver Çiçeği Sokak, No:14/8

Kadıköy - ISTANBUL / TURKEY 34714

e-mail: editor@rumelide.com,

phone: +90 5057958124, +90 2167730616 